\title{
Hvem fortjener en plass på forfatterlisten?
}

I møte med klinikere og basalforskere hører jeg jevnlig kommentarer som «De skal stå på forfatterlisten selv om de bare har bidratt med isolering av DNA» - et eksempel på et hjertesukk fra en kliniker. Mens hjertesukket fra en basalforsker kan være: «De skal stå på forfatterlisten selv om de kun har bidratt med pasientopplysninger.» En fellesnevner for slike kommentarer kan være overvurdering av egen innsats eller manglende forståelse for andres, men er sannsynligvis først og fremst et tegn på et overfladisk samarbeid.

Når er så et bidrag vesentlig nok til at det kvalifiserer til medforfatterskap ifølge Vancouver-reglene $(1,2)$ ? Dette er det ikke alltid enkelt å avgjøre, særlig ikke hvis gruppen av potensielle forfattere til en artikkel mangler felles forståelse av verdien av de ulike bidragene. Uskrevne regler som har oppstått i ulike miljøer, kan også føre til uryddighet omkring det å etterkomme de formelle kriteriene. De to hjertesukkene over kategoriserer bidragene som rent tekniske eller rent administrative fra henholdsvis klinikeren og basalforskeren. Dette berører kanskje noe av kjernen i problemet basalforskere eller klinikere får en avgrenset bestilling, uten å bli trukket inn i den vitenskapelige diskusjonen. Basalforskeren får da en tilsvarende rolle som en ansatt $i$ en teknisk stilling og klinikeren en administrativ rolle. For teknisk personell er det varierende praksis om de havner på forfatterlisten eller $\mathrm{i}$ «acknowledgements». Mitt inntrykk er at de i økende grad er medforfattere. Dette kan skyldes høyere utdanningsnivå og mer avansert teknologi, men også at de slipper til i den vitenskapelige diskusjonen. For akademiske stillinger har det vært mer en selvfølge at et metodisk bidrag fører til medforfatterskap. Det er også ofte blitt tatt for gitt at klinikeren skal være medforfatter hvis basalforskeren skal få tilgang på kliniske data.

Lange publikasjonslister som enten skyldes at man er ekspert på en ettertraktet metode eller god på å gjenbruke pasientdata, kan være provoserende for dem som ikke har slike fortrinn. Av og til gjøres det avtaler om at en person kan være med som medforfatter på et visst antall artikler hvis bidraget er av en slik karakter, for å unngå en uforholdsmessig og urettmessig stor grad av premiering. En slik bonusordning er imidlertid ikke lett å håndtere hvis det ikke er enighet partene imellom, og det kan stilles spørsmål ved hvor etisk god den er.

Det ideelle er selvsagt at bidragsyterne har god nok evne til å vurdere sitt eget bidrag, slik at ubehagelige diskusjoner kan unngås. Jeg har erfart - og er av og til blitt overrasket over - at forskere i et samarbeidsprosjekt selv ber om å bli utelatt fra forfatterlisten, eventuelt at de flyttes til «acknowledgements», fordi de ikke anser bidraget sitt som vesentlig nok. Dette har vært både for laboratorieresultater og kliniske data. Men hvor gode er forskere til å gjøre en vurdering av om de fortjener en plass på forfatterlisten? Internasjonale undersøkelser antyder at de ikke er så gode og at kriteriene for forfatterskap ofte ikke er oppfylt (3-6).
Vancouver-reglene er nok godt kjent for de fleste som publiserer i medisinske tidsskrifter, men kanskje ikke alle er klar over at det nylig har vært en innskjerping av disse $(7,8)$. I et fjerde punkt blir det gjort tydelig at forfatterskap innebærer ansvar for hele artikkelen. En medforfatter må akseptere at ethvert problem knyttet til artikkelen også er hans/hennes problem. Dette gjelder uansett om bidraget er pasientrekruttering eller laboratorieanalyser.

Jeg har ikke funnet studier der man tar opp medforfatterskap når basalforskere og kliniske forskere publiserer sammen. Imidlertid er det publisert studier om hvordan parakliniske disipliner hevder seg i klinisk forskning. En studie med utgangspunkt i Canadian Medical Association Journal har konkludert med at patologer og radiologer for sjelden er å finne på forfatterlistene når det presenteres data fra disse spesialitetene (9). En annen undersøkelse viste at laboratoriemedisinere er underrepresentert på forfatterlistene i de generelle medisinske tidsskriftene med høy impaktfaktor i studier som omfatter laboratoriemedisin (10).

Det kan fort bli et dårlig klima for samarbeid hvis det stilles spørsmål ved om samarbeidspartnerens bidrag er godt nok til medforfatterskap, men det kan bli spiren til et mer fruktbart samarbeid. I stedet for at basalforskeren sukker over at det tidkrevende laboratoriearbeidet ikke blir verdsatt godt nok og den kliniske forskeren hevder at laboratorieforskeren ikke forstår hvor mye arbeid det ligger bak de kliniske data, kunne de invitere hverandre til diskusjoner innenfor sitt eget fagområde. En bro mellom grunnforskning og klinisk forskning er selve fundamentet for translasjonsforskningen, som sykehusene har et særskilt ansvar for (11).

\section{Litteratur}

1. Recommendations for the Conduct, Reporting, Editing and Publication of Scholarly Work in Medical Journals. www.icmje.org/\#author (15.11.2013). 2. Hem E. Hva er en forfatter? Tidsskr Nor Legeforen 2012; 132: 381

3. Marusić M, Bozikov J, Katavić V et al. Authorship in a small medical journal: a study of contributorship statements by corresponding authors. Sci Eng Ethics 2004: 10: 493-502

4. Pignatelli B, Maisonneuve $H$, Chapuis F. Authorship ignorance: views of researchers in French clinical settings. J Med Ethics 2005; 31: 578-81.

5. Martinson BC, Anderson MS, de Vries R. Scientists behaving badly. Nature 2005; 435: 737-8.

6. Malički M, Jerončić $A$, Marušić $M$ et al. Why do you think you should be the author on this manuscript? Analysis of open-ended responses of authors in a general medical journal. BMC Med Res Methodol 2012; 12: 189

7. The New ICMJE Recommendations. http://icmje.org/new_recommendations.html (15.11.2013).

8. Haug C. Krav til forfattere. Tidsskr Nor Legeforen 2013; 133: 1545

9. Franko AD, Wright JR Jr, Trotter MJ. Underrecognition of pathologist contributions to articles published in a major multidisciplinary medical journal. Am J Clin Pathol 2012; 138: 495-7.

10. Escobar PM, Nydegger U, Risch M et al. The intellectual contribution of laboratory medicine professionals to research papers on laboratory medicine topics published in high-impact general medicine journals. Clin Chem Lab Med 2012; 50: $1305-8$.

11. Helse- og omsorgsdepartementet. Forskning. www.regjeringen.no/nb/dep/hod/ tema/sykehus/nokkeltall-og-fakta---ny/sykehusenes-hovedoppgaver-/ forskning.html?id=528640 (15.11.2013). 